\title{
EUGERRES CASTROAGUIRREI GONZÁLEZ-ACOSTA ET RODILES-HERNÁNDEZ, 2013 IS A JUNIOR SYNONYM OF EUGERRES MEXICANUS (STEINDACHNER, 1863) (ACTINOPTERYGII: PERCIFORMES: GERREIDAE)
}

\author{
Adriana MARTÍNEZ-GUEVARA ${ }^{1}$, Francisco Javier GARCÍA-RODRÍGUEZ², Víctor Manuel \\ COTA-GÓMEZ², Raúl Enrique HERNÁNDEZ-GÓMEZ³, Martha Alicia PERERA-GARCÍA, \\ and José DE LA CRUZ-AGÜERO²*
}

${ }^{1}$ Facultad de Ciencias Biológicas y Agropecuarias, Universidad Veracruzana, Programa de Biología Marina, Veracruz, Mexico

${ }^{2}$ Instituto Politécnico Nacional, Centro Interdisciplinario de Ciencias Marinas, Colección Ictiológica, La Paz, Baja California Sur, México

${ }^{3}$ Ingeniería en Acuacultura, División Académica Multidisciplinaria de los Ríos, Universidad Juárez Autónoma de Tabasco, Tenosique, Tabasco, México

Martínez-Guevara A., García-Rodríguez F.J., Cota-Gómez V.M., Hernández-Gómez R.E., Perera-García M.A., De La Cruz-Agüero J. 2015. Eugerres castroaguirrei González-Acosta et Rodiles-Hernández, 2013 is a junior synonym of Eugerres mexicanus (Steindachner, 1863) (Actinopterygii: Perciformes: Gerreidae). Acta Ichthyol. Piscat. 45 (4): 393-401.

Background. The Lacandon mojarra, Eugerres castroaguirrei González-Acosta et Rodiles-Hernández, 2013, was described from the Grijalva-Usumacinta River basin (Mexico). According to the diagnosis E. castroaguirrei differs from the only other freshwater Gerreidae, the Mexican mojarra, Eugerres mexicanus (Steindachner, 1863) by the combination of certain morphological characters. However, a comparison of materials obtained in the Usumacinta River, besides of type materials and other preserved specimens, yielded contradictory results. Therefore, the objective of this paper was to clearly determine if E. mexicanus and E. castroaguirrei are subjective synonyms applying morphological and molecular analyses.

Materials and methods. A total of 44 specimens were included in this study including the specimens collected specifically for this study, the type and non-type materials of Eugerres castroaguirrei from Colección de Peces de El Colegio de la Frontera Sur, Unidad San Cristóbal, Chiapas, México, and the types of Eugerres mexicanus, belonging to the Museum of Natural History, Wien, Austria. The morphological comparison also included data from the 42 specimens of $E$. castroaguirrei reported in the new species description. Biometric data were analysed as body proportions. We used Friedman's test to compare our biological materials with those used in the new species description. Molecular genetics comparisons on both putative freshwater gerreid species were made based on three mitochondrial gene fragments: 12SrRNA, 16SrRNA, and Cytochrome Oxidase subunit I (COI), and the nuclear gene: Recombination-Activating protein 1 (RAG1).

Results. Neither the non-parametric Friedman's test nor the Nemenyi's procedure showed differences among individuals for both putative species in multiple pair-wise comparisons of body proportions. Moreover, the genetic divergence from all genes indicated that all individuals exhibited almost identical sequences, with inter-specific pair-wise genetic distances that ranged from $0.00 \%$ to $0.100 \%$ in all of the fragments.

Conclusion. Our morphological and molecular genetics analyses demonstrated that E. mexicanus and E. castroaguirrei are subjective synonyms, therefore, Eugerres mexicanus (Steindachner, 1863) must be considered a valid species name, and Eugerres castroaguirrei González-Acosta et Rodiles-Hernández, 2013 a junior synonym.

Keywords: Mexican mojarra, taxonomy, synonymy, morphology, molecular genetics 


\section{INTRODUCTION}

The Neotropical gerreid genus Eugerres Jordan et Evermann, 1927 has long been recognized as comprising at least six marine and brackish water species (Froese and Pauly 2015), in addition to the only freshwater member of Gerreidae: the white- or Mexican mojarra, Eugerres mexicanus (Steindachner, 1863). Recently, a new freshwater species, the Lacandon mojarra, Eugerres castroaguirrei González-Acosta et Rodiles-Hernández, 2013 from the Grijalva-Usumacinta River basin of south-eastern Mexico and northern Guatemala was described (González-Acosta and Rodiles-Hernández 2013).

As stated by González-Acosta and Rodiles-Hernández (2013), both of these restricted freshwater gerreid species are distinguishable from their marine estuarine congeners by the dorsal fin origin which is posterior to the insertion of the pectoral and pelvic fins, and possess a shorter and broad based supraoccipital crest. According to the new species diagnosis, Eugerres castroaguirrei differs from Eugerres mexicanus by the combination of the following characteristics: length of second dorsal-fin spine $23.2 \%-34.2 \%$ SL (vs. $18.9 \%-43.3 \%$ SL in E. mexicanus), length of second anal-fin spine $11.1 \%-20.6 \% \mathrm{SL}$ (vs. $16.7 \%-30.2 \%$ SL), orbit diameter $23.3 \%-31.5 \%$ HL (vs. 26.5\%-45.3\% SL), pelvic-fin spine in the first pelvic-fin ray length $49.7 \%-65.0 \%$ SL (vs. $42.3 \%-78.2 \%$ SL), depressed second dorsal-spine extending to base of third or fourth dorsal-fin rays (vs. extending to base of fifth and sixth dorsal-fin rays), depressed second anal-fin spine extending to base of third or fourth anal fin-ray (vs. extending to base of eighth anal fin-ray), and lower lips ventrally extending to midpoint of eye (vs. not reaching anterior margin of the orbit).

However, a comparison of materials obtained in the Usumacinta River (Tenosique, Tabasco) using the measurements, descriptions and diagnosis of type materials, yielded contradictory results. From these results, it is likely that Eugerres mexicanus and Eugerres castroaguirrei are subjective synonyms. Therefore, this confusion about having both E. mexicanus and E. castroaguirrei as names for the same freshwater gerreid species should be taxonomically solved.

The aim of the presently reported study was to determine accurately whether Eugerres mexicanus and Eugerres castroaguirrei are the same species. The two putative species are evaluated by statistical analyses of morphological characters using the same measurement protocol approached by the authors of the new species, and by analysing the sequence divergence of three mitochondrial gene fragments: 12SrRNA, 16SrRNA, and Cytochrome Oxidase subunit I (COI), and the nuclear gene: Recombination-Activating protein 1 (RAG1) to compare the genetic distance between them.

\section{MATERIALS AND METHODS}

Fish collection and taxonomic determination. Considering the selected specimens from two field sampling (composed of 117 fish), type materials, and additional museum specimens, a total of 44 individuals were included in this study. Fish were collected on 26 April 2012 and 22 March 2013 , using a seine net with mesh size of $4 \times 4 \mathrm{~cm}, 80 \mathrm{~m}$ long, and $3 \mathrm{~m}$ wide, at the Recreo locality $\left(17^{\circ} 28^{\prime} 52^{\prime \prime} \mathrm{N}\right.$ and $91^{\circ} 25^{\prime} 17^{\prime \prime} \mathrm{W}$ ) in the Usumacinta River, Tenosique Municipality, Tabasco, Mexico. All the caught fish ranged in size from 155.0 to $183.0 \mathrm{~mm}$ standard length (SL; mean $=167.8 \mathrm{~mm}$ ), these were preserved in a $10 \%$ formalin solution, however, prior to preservation a small piece of muscle tissue from the pectoral left side of 8 specimens was preserved in $96 \%$ ethanol for molecular analyses. The collected fish are held in the Ichthyological Collection (CI) from Centro Interdisciplinario de Ciencias Marinas (CICIMAR-CI 8810-11). The taxonomic determination of field-collected and museum specimens was carried out under a stereomicroscope according to the morphological characteristics described in the reference diagnosis for both species by Deckert and Greenfield (1987) and González-Acosta and Rodiles-Hernández (2013), and also to additional criteria established by Castro-Aguirre et al. (1999) for the species Eugerres mexicanus. It should be emphasized that González-Acosta and Rodiles-Hernández (2013) did not include a dichotomous key for species identification, and that all of the measurable diagnostic characters figured for Eugerres castroaguirrei are overlapped with those of E. mexicanus (see Introduction section herein, and González-Acosta and Rodiles-Hernández 2013; Pp. 309-310). Hence, the fish selected from the whole sample presented similar size and body proportions equivalent to those mentioned as diagnostic for $E$. castroaguirrei. Moreover, we also used the non-measurable morphological characters indicated as diagnostic by González-Acosta and Rodiles-Hernández (2013) (excluding lower lips ventrally extending to midpoint of eye, see Discussion), in order to group the two morphotypes or putative species: body oblong and laterally ticker in E. castroaguirrei (vs. deep and laterally compressed in E. mexicanus), dorsal-fin origin posterior to the insertion of the pectoral and pelvic fins (vs. anterior to the insertion of the pectoral and pelvic fins), depressed second dorsal-spine extending to base of third or fourth dorsal-fin rays (vs. depressed second dorsal-spine extending to base of fifth or sixth dorsal-fin rays), and depressed second anal-fin spine extending to base of third or fourth anal fin-rays and not reaching the distal point of last anal-fin ray (vs. depressed second anal-fin spine extending to base of eighth anal fin-ray and reaching the distal point of last anal-fin ray). It is relevant to emphasize that from the whole analysed sample (i.e., field-collected fish, type and nontype materials), not all of the specimens were consistent with the totality of these non-measurable characteristics mentioned by González-Acosta and Rodiles-Hernández (2013) as diagnostic for E. castroaguirrei. Hence, the selected specimens identified as E. castroaguirrei from the whole sample, include only those individuals that meet with most of the non-measurable diagnostics characters and quasi-equivalent body proportions to the quoted for the new species. 
Morphological comparison. Morphological measurements were taken to the nearest $\mathrm{mm}$ according to González-Acosta and Rodiles-Hernández (2013) criterion. A total of 11 linear body measurements were used, from which 15 body proportions were derived, corresponding to those used in the new species description. The measured fish include the holotype of the Lacandon mojarra, Eugerres castroaguirrei, that belongs to the Coleccion de Peces de El Colegio de la Frontera Sur, Unidad San Cristóbal, Chiapas, México (ECOSC 775; Fig. 1a), the non-type specimens listed by González-Acosta and Rodiles-Hernández (2013; ECOSC 750,110, 694, 1570, 704, 689, 641, 2191), and the lectotype (NMW 72289; Fig. 1b), and two paralectotypes (NMW 78820-1, NMW 78820-2) of the Mexican mojarra, Eugerres mexicanus, belonging to the Museum of Natural History, Wien, Austria (NHM). Additionally, other specimens of the Mexican mojarra were included (ECOSC 047, 380, 431, 587, 398, 048, 302; and aforementioned CICIMAR-CI 8810-11), thus, a total of 44 specimens were considered for the analysis. Definitions of measurements, proportions, and their abbreviations are shown by González-Acosta and Rodiles-Hernández (2013; Pp. 308-309). Biometric data were analysed as proportions of standard length $(\% \mathrm{SL}$; five body proportions), body depth (\%BD; two body proportions), head length ( $\% \mathrm{HL}$; five body proportions), and three other body proportions, as suggested in the original description of E. castroaguirrei. In addition to the fish sample described above, comparisons also include the data set of 42 specimens of E. castroaguirrei (six type specimens, plus 35 non-type specimens; SL: 114.6 to $241.7 \mathrm{~mm}$; mean $=201.0 \mathrm{~mm}$ ) and 125 specimens of E. mexicanus (three type specimens, plus 122 non-type specimens; SL: 43.7 to $193.0 \mathrm{~mm}$; mean $=146.4 \mathrm{~mm}$ ), that were reported in the description of the new species by González-Acosta and Rodiles-Hernández (2013; Pp. 309-310). Because of the statistical nature and sample size of both data sets, we used Friedman's test $(\mathrm{Ft})$ to compare our measured materials (i.e., body measures and body proportions of type and non-type specimens) with those used in Eugerres castroaguirrei species description. Ft is a non-parametric test used to compare repeated observations on the same subjects belonging to three or more paired groups. It is also called non-parametric randomized block analysis of variance. However, Ft test makes no assumptions about data distribution (i.e., normality or equality of variance), as opposed to parametric repeated measures ANOVA, or a paired $t$-test (Zar 2010). The post-hoc test used was the Nemenyi's procedure analogous to Tukey test, but using ranked sums instead of means. Considering the fact that there were multiple comparisons among the specimens, the Bonferroni correction was used (i.e., significance level divided by the number of tests or comparisons). A probability of $P<0.05$ was used as statistical significance criterion.

Molecular genetics comparisons. Three mitochondrial gene fragments: 12SrRNA, 16SrRNA, and Cytochrome Oxidase subunit I (COI), and the nuclear gene: Recombination-Activating protein 1 (RAG1) were amplified. Genom- ic DNA was extracted from pectoral muscle tissue samples of each selected specimen $(n=8$; five specimens for the species Eugerres mexicanus and three for the putative species Eugerres castroaguirrei; see Fig. 2) using the QIAGEN $^{\circledR}$ DNeasy Blood and Tissue kit (Catalogue No. Q0169506, Hilden, Germany) following the manufacturer's protocol. The mitochondrial and nuclear gene fragments were amplified by Polymerase Chain Reaction (PCR), using the primers L1091 and H1478 for 12SrRNA (Kocher et al. 1989); 16Sar-L and 16Sbr-H for 16SrRNA (Palumbi 1996); FishF1 and FishR1 for COI (Ward et al. 2005); and DauraRAG1F1-DauraRAG1R1 (Vergara-Solana et al. 2014). Each reaction was made using a $35 \mu \mathrm{L}$ volume containing: 1X of PCR Buffer $\left(\mathrm{MgCl}_{2}\right), 0.2 \mathrm{mM}$ of dNTP mix, $0.48 \mu \mathrm{M}$ of each primer, $4 \mathrm{mM}$ of $\mathrm{MgCl}_{2}$, and $0.05 \mathrm{U}$. $\mu \mathrm{L}^{-1}$ of Taq DNA polymerase (Invitrogen ${ }^{\circledR}$, Carlsbad, CA, USA). An amount of $0.7 \mu \mathrm{L}$ of total DNA was included to each reaction. Thermal cycler conditions for amplification consisted of an initial phase of $2 \mathrm{~min}$ at $94^{\circ} \mathrm{C}$, followed by 35 cycles, and a final extension for $4 \mathrm{~min}$ at $72^{\circ} \mathrm{C}$. Each of the 35 cycles consisted of three steps: (i) $1 \mathrm{~min}$ at $94^{\circ} \mathrm{C}$; (ii) $1 \mathrm{~min}$ at $58^{\circ} \mathrm{C}$ for 12 and $16 \mathrm{~s} ; 1 \mathrm{~min}$ at $66.5^{\circ} \mathrm{C}$ for RAG1, and $30 \mathrm{~s}$ at $54^{\circ} \mathrm{C}$ for COI; (iii) $2 \mathrm{~min}$ at $72^{\circ} \mathrm{C}$. The PCR products were visualized on $1 \%$ agarose gels prior to $\mathrm{pu}-$ rification and sequencing, using forward and reverse primers for each gene (Macrogen ${ }^{\circledR}$, Seoul, Korea). Sequences were arranged and edited using Geneious Pro version 5.6.7 (Biomatters ${ }^{\circledR}$ Ltd., Auckland, New Zealand). Multiple alignments using the MUSCLE algorithm (Edgar 2004) were made and tree constructions, as well as the calculation of pair-wise genetic distances were conducted using the MEGA software version 5 (Tamura et al. 2011). The genetic distances among and within species for COI and RAG1 genes, were estimated using the Kimura two-parameter (K2P) substitution model (Kimura 1980). Since only one sequence of $E$. castroaguirrei and one of E. mexicanus were used for 12SrRNA and for 16SrRNA, genetic distances within species could not be estimated. To eliminate the effect of intraspecific variation, the net distance was estimated (Tamura et al. 2011). Neighbour-Joining (NJ; Saitou and Nei 1987) trees based on K2P were constructed for each molecular genetic marker to provide a graphic representation of the divergence among species. The robustness of the internal branches in the trees was supported by 1000 bootstrap replications (Felsenstein 1985). This analysis was performed with MEGA5 (Tamura et al. 2011). The sequences were deposited in GenBank (accession numbers, COI: KM014793-KM014800; 12SrRNA: KT149515149516; 16SrRNA: KT149517-149518; RAG1: KM014801-KM014808). The COI, 12SrRNA, 16SrRNA, and RAG1 sequences of the putative E. castroaguirrei and $E$. mexicanus were analysed together with those specimens from their marine Atlantic congeners, the stripped mojarra, Eugerres plumieri (Cuvier, 1830) (GenBank accession numbers for COI: GU225264.1, GU225263.1, and GU225262.1; for 12SrRNA: EF095572.1; for 16SrRNA: EF095600.1; and for RAGI: EF095665 and JX189821.2); and the Brazilian mojarra, Eugerres brasilianus (Cuvier, 1830) (GenBank accession numbers for COI: JQ365353.1, 


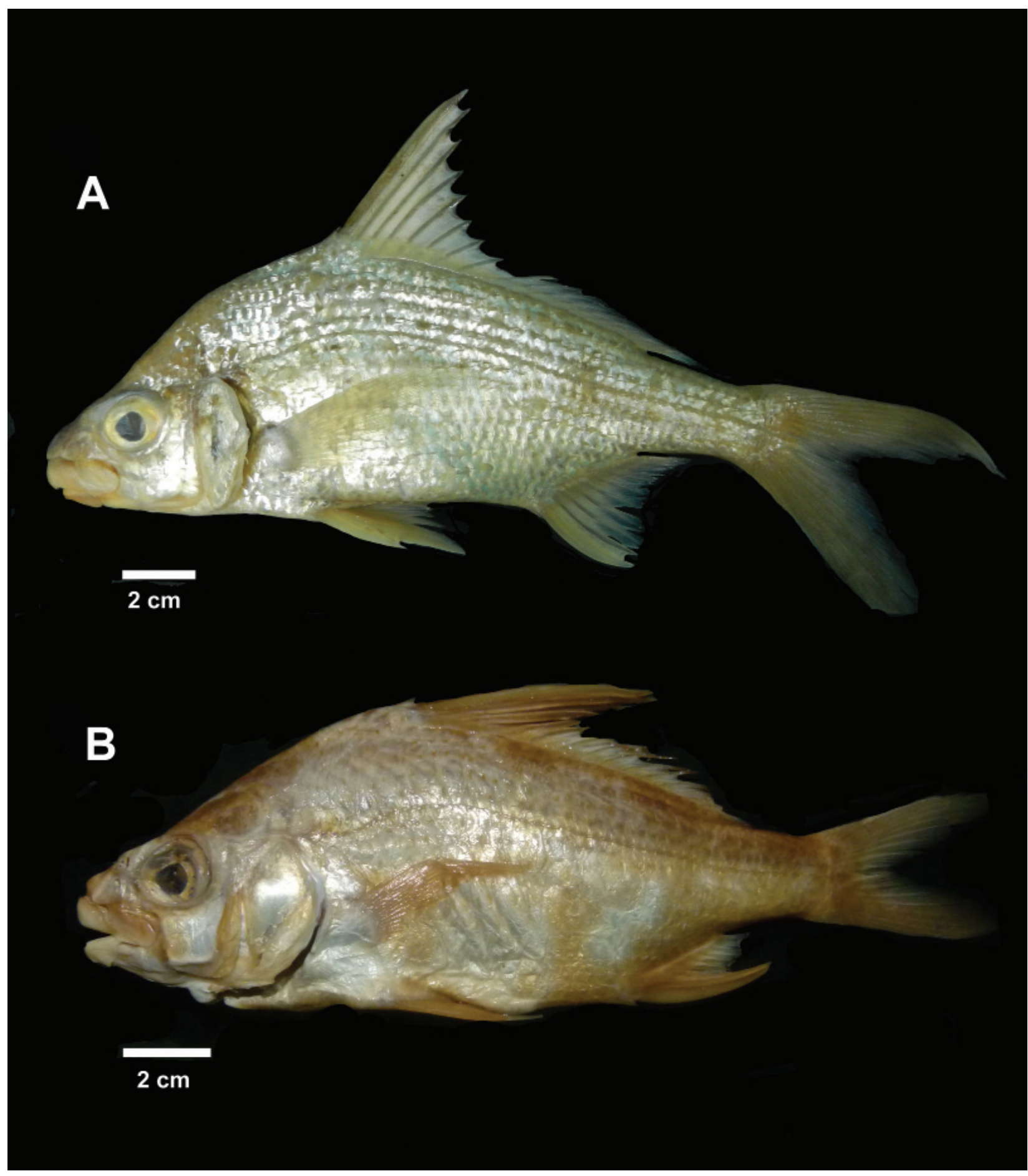

Fig. 1. Eugerres castroaguirrei González-Acosta et Rodiles-Hernández, 2013, synonym (ECOSC 775), 189.63 mm SL. México, Chiapas, Lacandona Rainforest, Lacantún River, between Reforma Agraria and Galaxia (A); Eugerres mexicanus (Steindachner, 1863), lectotype (NMW 72289), 168.40 mm SL. México, Tabasco, Teapa River (B)

JQ365351.1, and JQ365350.1; for 12SrRNA: KT06785067852; for 16SrRNA: KT067877 and KT067878; and for RAGI: KT067898-67900).

\section{RESULTS}

Morphological comparisons. The results of Friedman's Q statistics used to compare data of each specimen for all measurements and proportions in both data sets were: $Q_{\text {c }}$ $($ critical $)=9.487$ and $Q_{\mathrm{o}}($ observed $)=4.800(P<0.3084$, $\alpha=0.05 ; \mathrm{df}=4)$. The $P$-value suggested that the probability of making an error in rejecting the null hypothesis was $30.84 \%$. Hence, the null hypothesis which stated that there was no difference among specimens in both data sets was then accepted, i.e., the interspecific sample was not significantly different. An additional test, but without considering the inclusion of the dorsal and anal spines, increases the probability of acceptance of the null hypothesis, i.e., the risk of rejecting the null hypothesis when true 

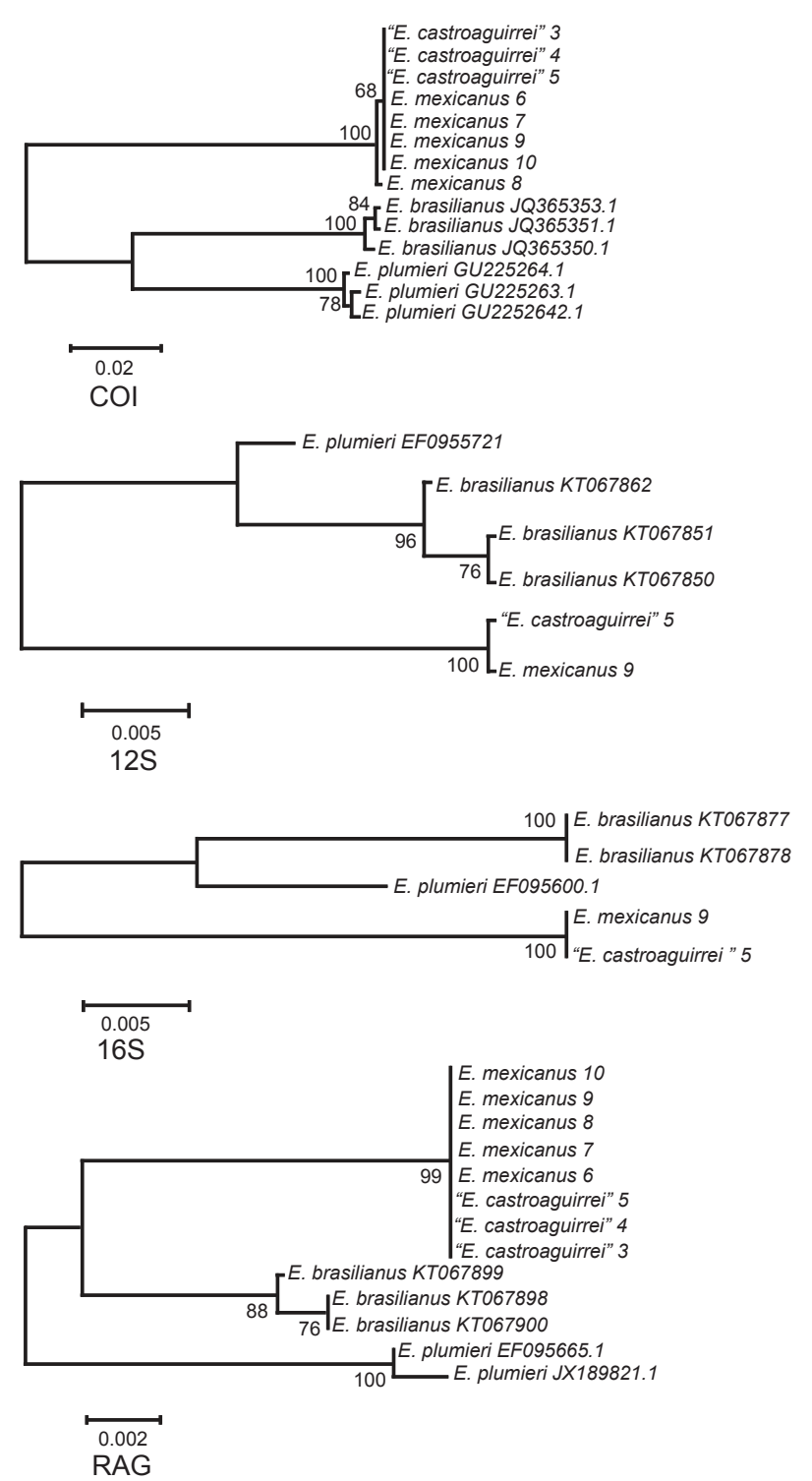

Fig. 2. Molecular genetics analyses of Eugerres spp. based on Neighbour Joining methods, Kimura 2-parameter model, and 1000 bootstrap replicates for COI, $12 \mathrm{Sr}$ RNA, 16SrRNA, and RAG1 genes; Putative species Eugerres castroaguirrei is shown in quotation marks; note that GenBank accession numbers cited in the text correspond to Eugerres mexicanus; Numbers located beside the branch indicate bootstrap values above $50 \%$; Scale bar is presented according to Kimura 2-parameter model (K80); The code beside E. brasilianus and E. plumieri represents the GenBank accession numbers

is $36.69 \%\left(Q_{\mathrm{c}}=9.487, Q_{\mathrm{o}}=4.300 ; P<0.3669, \alpha=0.05\right)$. The Nemenyi's procedure did not show differences among individuals in multiple pair-wise comparisons either (Table 1). Similar results (i.e., there were no significant differences among the compared groups) were obtained by calculating independent $\mathrm{Ft}$ tests considering the different body plan proportions of Table 1 from González-Acosta and Rodiles-Hernández (2013), i.e., percentage of standard length, percentage of body depth, percentage of head length, and other body proportions.
Molecular and genetic comparisons. The Mexican mojarra and the Lacandon mojarra could not be distinguished from each other with COI, 12SrRNA, 16SrRNA, and RAG1 sequences (Fig. 2). Based on 670 base pairs (bp) that contained 669 conserved sites and only one variable site, the intra-specific genetic variation for the COI was $0.1 \%$ in Eugerres mexicanus and it was absent in Eugerres castroaguirrei. The variable nucleotide site found rather represents a polymorphic site in E. mexicanus not a divergent site between both putative species (i.e., all individuals of E. castroaguirrei exhibited haplotypes found in E. mexicanus). Species clades were not supported by high bootstrap values of $100 \%$ (Table 2 and Fig. 2). Since the inter-specific pair-wise genetic distance between $E$. mexicanus and E. castroaguirrei was null, these two putative species could not be separated from one another (Fig. 2). Among the four analysed Eugerres species, including the marine congeners E. brasilianus and E. plumieri, the overall inter-specific pair-wise genetic distances ranged from $0.0 \%$ to $15.4 \%$. Thus, the differences between $E$. mexicanus and E. castroaguirrei specimens, in relation to the found among freshwater specimens and others from its marine congeners, allowed the discrimination of only three species-groups (i.e., species; Table 2 and Fig. 2).

Regarding the inter-specific estimated genetic distances for 12SrRNA and 16SrRNA fragments, these showed no differences and indicated that all of the analysed specimens of Eugerres mexicanus and Eugerres castroaguirrei have identical sequences between them $(0.0 \% \pm 0.0 \%)$. Differences among the four analysed Eugerres species ranged from $0.0 \%$ to $4.2 \%$ for $12 \mathrm{SrRNA}$ and from $0.0 \%$ to $5.0 \%$ for 16 SrRNA (Table 2).

Similarly, in RAG1 fragment (based on $673 \mathrm{bp}$ ), Eugerres mexicanus and Eugerres castroaguirrei could not be differentiated from each other, because sequences were identical in the two putative species (Table 2, Fig. 2). Inter-specific differences ranged from $0.0 \%$ to $2.1 \%$, with the largest difference among E. plumieri and both putative freshwater species (2.1\%) (Table 2 and Fig. 2).

\section{DISCUSSION}

The comparisons carried out in this study, clearly demonstrate that the specimens of Eugerres mexicanus and Eugerres castroaguirrei were not different neither genetically nor in their morphological characters, hence, they should not be considered as different species.

In addition to aforementioned, all measurable diagnostic characters figured for $E$. castroaguirrei are overlapped with those of E. mexicanus. Therefore, the selected specimens identified as E. castroaguirrei were chosen due to their size and body proportions, and because they meet most of the non-measurable diagnostic characters cited for the new species, excluding lower lips ventrally extending to midpoint of eye, it is worth to mention that this is as well a lacking characteristic even in the examined holotype (ECOSC 775; Fig. 1a). See also figure 3a in González-Acosta and Rodiles-Hernández (2013; Pp. 309-310).

Regarding the considerable overlap in the measurable characteristics and inconsistencies for non-measurable di- 
Table 1

Nemenyi's procedure, a post-hoc test of the Friedman's test, among the specimens of Eugerres mexicanus collected

(1C) and type materials in the presently reported study (Eugerres mexicanus 1T and Eugerres castroaguirrei 1T)

and those reported by González-Acosta and Rodiles-Hernández (2013; P. 309) as type and non-type materials

(E. castroaguirrei 2 and E. mexicanus 2), using body measures and body proportions; Pair-wise differences among groups above diagonal, $P$ values below diagonal

\begin{tabular}{lccccc}
\hline & E. castroaguirrei 2 & E. mexicanus 2 & E. mexicanus 1T & E. castroaguirrei 1T & E. mexicanus 1C \\
\hline E. castroaguirrei 2 & - & 0.8325 & 0.2353 & 0.0588 & 0.3529 \\
E. mexicanus 2 & 0.5503 & - & 1.0588 & 0.8824 & 0.4706 \\
E. mexicanus 1T & 0.9926 & 0.2897 & - & 0.1765 & 0.5882 \\
E. castroaguirrei 1T & 1.0000 & 0.4800 & 0.9976 & - & 0.4118 \\
E. mexicanus 1C & 0.9665 & 0.9087 & 0.8146 & 0.9421 & - \\
\hline
\end{tabular}

Bonferroni corrected significance level: $0.0049 ; \alpha=0.05$; Degrees of freedom $=4$; Critical difference $=1.4794$.

Table 2

Pair-wise genetic K80-distances for the investigated species of Eugerres spp. based on four selected genes

\begin{tabular}{|c|c|c|c|c|c|}
\hline $\mathrm{G}$ & & E. mexicanus & E. castroaguirrei & E. brasilianus & E. plumieri \\
\hline \multirow{5}{*}{ Ö } & E. mexicanus & $0.1 \pm 0.000$ & & & \\
\hline & E. castroaguirrei & $0.00 \pm 0.000$ & $0.00 \pm 0.000$ & & \\
\hline & E. brasilianus & $15.4 \pm 0.017$ & $15.4 \pm 0.018$ & $0.5 \pm 0.002$ & \\
\hline & E. plumieri & $14.9 \pm 0.017$ & $15.0 \pm 0.017$ & $10.0 \pm 0.013$ & $0.3 \pm 0.002$ \\
\hline & Distance overall mean: & \multicolumn{4}{|c|}{$9.2 \pm 0.009$} \\
\hline \multirow{5}{*}{ 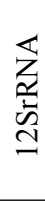 } & E. mexicanus & $\mathrm{n} / \mathrm{a}$ & & & \\
\hline & E. castroaguirrei & $0.00 \pm 0.000$ & $\mathrm{n} / \mathrm{a}$ & & \\
\hline & E. brasilianus & $4.2 \pm 0.010$ & $4.2 \pm 0.010$ & $0.1 \pm 0.001$ & \\
\hline & E. plumieri & $3.4 \pm 0.009$ & $3.4 \pm 0.009$ & $1.3 \pm 0.005$ & $\mathrm{n} / \mathrm{a}$ \\
\hline & Distance overall mean: & \multicolumn{4}{|c|}{$2.4 \pm 0.007$} \\
\hline \multirow{5}{*}{ 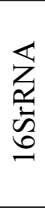 } & E. mexicanus & $\mathrm{n} / \mathrm{a}$ & & & \\
\hline & E. castroaguirrei & $0.00 \pm 0.000$ & $\mathrm{n} / \mathrm{a}$ & & \\
\hline & E. brasilianus & $5.0 \pm 0.011$ & $5.0 \pm 0.011$ & $0.00 \pm 0.000$ & \\
\hline & E. plumieri & $4.2 \pm 0.009$ & $4.2 \pm 0.009$ & $2.6 \pm 0.007$ & $\mathrm{n} / \mathrm{a}$ \\
\hline & Distance overall mean: & \multicolumn{4}{|c|}{$3.3 \pm 0.007$} \\
\hline \multirow{5}{*}{$\begin{array}{l}\bar{\coprod} \\
\end{array}$} & E. mexicanus & $0.00 \pm 0.000$ & & & \\
\hline & E. castroaguirrei & $0.00 \pm 0.000$ & $0.00 \pm 0.000$ & & \\
\hline & E. brasilianus & $5.0 \pm 0.011$ & $5.0 \pm 0.011$ & $0.1 \pm 0.000$ & \\
\hline & E. plumieri & $2.1 \pm 0.005$ & $2.1 \pm 0.005$ & $1.6 \pm 0.005$ & $0.1 \pm 0.001$ \\
\hline & Distance overall mean: & \multicolumn{4}{|c|}{$1.1 \pm 0.002$} \\
\hline
\end{tabular}

Values are mean \pm standard error of the mean (Kimura 2-parameter; Kimura 1980); Distances are presented as percentages; $G=$ gene.

agnostic characters cited as such by González-Acosta and Rodiles-Hernández (2013), it would appear that the morphological differences observed by these authors are the result of intra-specific polymorphism coupled with a phenotypic plasticity in Eugerres mexicanus. Phenotypic plasticity describes a profile of potential morphotypes from a fixed genotype affected by temporal and spatial variation of the environment (Lin and Dunson 1999). Such events are quite common in nature and environmental cues often result in behavioural or morphological development, that is, suited to local conditions (Adkison 1995; see also below).

The morphological comparison procedures calculated herein did not show differences among individuals of the different groups (i.e., putative species) in multiple pairwise comparisons. Differences were less significant when the analyses excluded dorsal and anal spines. In the whole sample, a high variability was observed in the length of these structures, with greater lengths in proportion to body length in small sized fish (i.e., allometric growth). Thereon numerous studies have shown that fish exhibit considerable morphometric variation throughout its distributional range that often results from competition for resources in heterogeneous environments (i.e., rapid or slow-moving complex environments and benthic or mostly limnetic habitat) or from spatial or temporal heterogeneity in predation intensity (Milano et al. 2002, Aguirre 2009). Also, the variability in morphometric traits of freshwater fish has been related to factors that are likely associated with colonization history (i.e., geography, direction of drainage, river basin, latitude) and current selection pressures (Milano et al. 2006).

The adaptation of fish to environmental stress such as high-gradient in habitats with rapid flow is well known to alter morphology, these modifications can include mor- 
phological alteration in their lips, body shape, and other associated structures (i.e., spines and rays) and colour patterns ( $\mathrm{Li}$ et al. 2013). Adaptation to benthic life both morphologically and physiologically, as in the Puyen grande, Galaxias platei Steindachner, 1898, for instance, entails several body modifications such as thickening of the upper and lower mouth lips (Matthews 1998), just as observed (with different levels of hypertrophy in lips) in several specimens of the Mexican mojarra. This species, reported as the 'thick-lipped' species of mojarras, has omnivorous feeding habits, involving the consumption of insects, plants, crustaceans, and molluscs (González-Acosta and Rodiles-Hernández 2013; Pp. 309-310). Although the exact function of the thickness in the lips of the Mexican mojarra is unknown (i.e., protection from mechanical shocks, specific foraging mode or the increase of taste receptors and mechanoreceptors), the 'fleshy' lips in freshwater fish are often interpreted as an adaptation for feeding on invertebrates and crustaceans hidden in crannies (Colombo et al. 2013, Baumgarten et al. 2015). In this respect, the sympatric distribution of both putative species, based on specimens collected in different habitats along Grijalva-Usumacinta basins (González-Acosta and Rodiles-Hernández 2013; p. 311), which displayed a highly overlapped morphological variability, seems to represent a panmictic population with trait variations that are environmentally induced by phenotypic plasticity (Goto et al. 2014).

The genetic data obtained from this study also support the taxonomic identity of the Eugerres spp. studied. Distance values in species, including organisms of the family Gerreidae, show that the amount of divergence of COI ranges from $3.70 \%$ to $16.05 \%$ (Asgharian et al. 2011). However, given that Eugerres mexicanus and Eugerres castroaguirrei shows null genetic distance for COI, 12SrRNA, 16SrRNA, and RAG1, we cannot support the existence of both species. In contrast, E. brasilianus and E. plumieri recorded high divergence values corresponding to previous results for the family Gerreidae (Chakraborty et al. 2006, Chen et al. 2007, Asgharian et al. 2010, Martínez-Guevara et al. 2014, Vergara-Solana et al. 2014). In this context, other authors have recommended the synonymization of taxa with high morphological similarity, based on identical gene sequences and low COI genetic variation (Carr et al. 1999, Byrkjedal et al. 2008), highlighting that morphological data and complementary molecular approaches allow to solve complex taxonomical situations where an unclear differentiation among species exists.

Taxonomy of Gerreidae species has been both confusing and an active issue of discussion among ichthyologists (De La Cruz-Agüero et al. 2012). Currently, eight genera are recognized in the family, nonetheless, the taxonomic status of more than 50 nominal species has not yet been revised and some gerreid taxa are still treated by some authors as species inquirendae (i.e., validity and/or generic assignment uncertain or questionable, sensu Vergara-Solana et al. 2014). The recent descriptions of new species in the family Gerreidae (Liu and Yan 2009, Iwatsuki et al. 2012), including the proposal of a new genus (Vergara-Solana et al. 2014), provide encouraging expec- tations on solving its taxonomic problems. However, these initiatives must be implemented with the maximum rigor, avoiding adding more taxonomic uncertainty in a group of fish that is taxonomically very complex.

In conclusion, we have clearly demonstrated that Eugerres mexicanus and Eugerres castroaguirrei are the same species, and in accordance with the Principle of Priority of the Code of Zoological Nomenclature (Anonymous 1999), Eugerres mexicanus (Steindachner, 1863) must be considered a valid species name, and Eugerres castroaguirrei González-Acosta et Rodiles-Hernández, 2013-its junior synonym.

\section{ACKNOWLEDGEMENTS}

This study was granted by Secretaria de Investigacion y Posgrado, Instituto Politecnico Nacional (SIP-IPN 20131432). J.D.A., F.J.G.R, and V.M.C.G. are fellows of Comisión de Operacion y Fomento de Actividades Académicas (COFAA-IPN), Estímulo al Desempeño de los Investigadores (EDI-IPN), and Sistema Nacional de Investigadores (SNI-CONACyT). The first author is a recipient of student fellowships from BEIFI-IPN, COFAA-IPN and CONACyT. AMG sincerely thanks to the fish curators and collection managers, A. Palandacic (Naturhistorisches Museum Wien, NHM) and R. Rodiles (ECOSUR-San Cristobal), for their help and assisting with the revision of the type materials. We thank M. Diaz-Santana for assistance in preparing the manuscript in English. The present paper is dedicated to the memory of Dr. J.L. Castro-Aguirre, on the fifth anniversary of his passing.

\section{REFERENCES}

Adkison M.D. 1995. Population differentiation in Pacific salmons: Local adaptation, genetic drift, or the environment? Canadian Journal of Fisheries and Aquatic Sciences 52: 2762-2777.

DOI: $10.1139 / \mathrm{f} 95-865$

Aguirre W.E. 2009. Microgeographical diversification of threespine stickleback: body shape-habitat correlations in a small, ecologically diverse Alaskan drainage. Biological Journal of the Linnean Society 98: 139-151. DOI: $10.1111 /$ j.1095-8312.2009.01267.x

Anonymous 1999. International Code of Zoological Nomenclature. 4th edn. International Commission on Zoological Nomenclature. http://www.nhm.ac.uk/hosted-sites/iczn/code/

Asgharian H., Elahi E., Kalirad A., Hosseinzadeh Sahafi H. 2010. Sequence data on four genes suggest nominal Gerres filamentosus specimens from Nayband National Park in the Persian Gulf represent two distinct species. Iranian Journal of Animal Biosystematics 6 (2): 1-11.

Asgharian H., Hosseinzadeh Sahafi H., Ardalan A.A., Shekarriz S., Elahi E. 2011. Cytochrome c oxidase subunit 1 barcode data of fish of the Nayband National Park in the Persian Gulf and analysis using meta-data flag several cryptic species. Molecular Ecology Resources 11 (3): 461-472.

DOI: $10.1111 /$ j.1755-0998.2011.02989.x 
Baumgarten L., Machado-Schiaffino G., Henning F., Meyer A. 2015. What big lips are good for: On the adaptive function of repeatedly evolved hypertrophied lips of cichlid fishes. Biological Journal of the Linnean Society 115 (2): 448-455.

DOI: $10.1111 /$ bij.12502

Byrkjedal I., Rees D.J., Christiansen J.S., Fevolden S.-E. 2008. The taxonomic status of Theragra finnmarchica Koefoed, 1956 (Teleostei: Gadidae): perspectives from morphological and molecular data. Journal of Fish Biology 73 (5): 1183-1200. DOI: $10.1111 /$ j.1095-8649.2008.01958.x

Carr S.M., Kivlichan D.S., Pepin P., Crutcher D.C. 1999. Molecular systematics of gadid fishes: Implications for the biogeographic origins of Pacific species. Canadian Journal of Zoology 77 (1): 19-26.

DOI: $10.1139 / 298-194$

Castro-Aguirre J.L., Espinosa-Pérez H.S., Schmiter-Soto J.J. 1999. Ictiofauna estuarino-lagunar y vicaria de México. Editorial Limusa-Noriega, México, D.F.

Chakraborty A., Venugopal M.N., Hidaka K., Iwatsuki Y. 2006. Genetic differentiation between two color morphs of Gerres erythrourus (Perciformes: Gerreidae) from the Indo-Pacific region. Ichthyological Research 53 (2): 185-188.

DOI: $10.1007 / \mathrm{s} 10228-005-0324-0$

Chen W.J., Ruiz-Carus R.R., Ortí G. 2007. Relationships among four genera of mojarras (Teleostei: Perciformes: Gerreidae) from the western Atlantic and their tentative placement among percomorph fishes. Journal of Fish Biology 70 (Supp. B): 202-218. DOI: $10.1111 / \mathrm{j} .1095-8649.2007 .01395 . \mathrm{x}$

Colombo M., Diepeveen E.T., Muschick M., Santos M.E., Indermaur A., Boileau N., Barluenga M., Salzburger W. 2013. The ecological and genetic basis of convergent thick-lipped phenotypes in cichlid fishes. Molecular Ecology 22 (3): 670-84.

DOI: $10.1111 / \mathrm{mec} .12029$

De La Cruz-Agüero J., García-Rodríguez F.J., De La Cruz-Agüero G., Díaz-Murillo B.P. 2012. Identification of gerreid species (Actinopterygii: Perciformes: Gerreidae) from the Pacific coast of Mexico based on sagittal otolith morphology analysis. Acta Ichthyologica et Piscatoria 42 (4): 297-306.

DOI: $10.3750 / A I P 2012.42 .4 .03$

Deckert G.D., Greenfield D.W. 1987. A review of the western Atlantic species of the genera Diapterus and Eugerres (Pisces: Gerreidae). Copeia 1987 (1): 182-194.

DOI: $10.2307 / 1446051$

Edgar R.C. 2004. MUSCLE: multiple sequence alignment with high accuracy and high throughput. Nucleic Acids Research 32 (5): 1792-1797.

DOI: $10.1093 /$ nar/gkh340

Felsenstein J. 1985. Confidence limits on phylogenies: An approach using the bootstrap. Evolution 39 (4): 783-791. DOI: $10.2307 / 2408678$

Froese R., Pauly D. (eds.) 2015. FishBase. [Version 09/2015] www.fishbase.org
González-Acosta A.F., Rodiles-Hernández R. 2013. New species of Eugerres from the Usumacinta Province, México and Guatemala with a redescription of E. mexicanus (Steindachner, 1863) (Teleostei: Gerreidae). Neotropical Ichthyology 11 (2): 307-318. DOI: $10.1590 /$ S1679-62252013000200009

Goto A., Arioka H., Yokoyama R. 2014. Plastic life-history variation along the course of a steep mountainous river in male Cottus hangiongensis (Pisces: Cottidae) Environmental Biology of Fishes 97 (8): 909-919. DOI: $10.1007 / \mathrm{s} 10641-013-0192-9$

Iwatsuki Y., Pogonoski J.J., Last P. 2012. Revision of the genus Parequula (Pisces: Gerreidae) with a new species from southwestern Australia. Zootaxa 3425: 42-54.

Kimura M. 1980. A simple method for estimating evolutionary rates of base substitutions through comparative studies of nucleotide sequences. Journal of Molecular Evolution 16 (2): 111-120.

DOI: $10.1007 / \mathrm{BF} 01731581$

Kocher T.D., Thomas W.K., Meyer A., Edwards S.V., Pääbo S., Villablanca F.X., Wilson A.C. 1989. Dynamics of mitochondrial DNA evolution in animals: Amplification and sequencing with conserved primers. Proceedings of the National Academy of Sciences $\mathbf{8 6}$ (16): 6196-6200.

Li J., Huang L., Sato T., Zou L., Jiang K., Yahara T., Kano Y. 2013. Distribution pattern, threats and conservation of fish biodiversity in the East Tiaoxi, China. Environmental Biology of Fishes 96 (4): 519-533. DOI: $10.1007 / \mathrm{s} 10641-012-0036-\mathrm{z}$

Lin H.-C., Dunson W.A. 1999. Phenotypic plasticity in the growth of the self-fertilizing hermaphroditic fish Rivulus marmoratus. Journal of Fish Biology 54 (2): 250-266. DOI: 10.1111/j.1095-8649.1999.tb00828.x

Liu J., Yan Y. 2009. A new species, Gerres septemfasciatus (Perciformes: Gerreidae) from the Chinese coastal waters of the South China Sea. Chinese Journal of Oceanology and Limnology 27 (3): 555-557. DOI: $10.1007 / \mathrm{s} 00343-009-9259-\mathrm{z}$

Martínez-Guevara A., García-Rodríguez F.J., De La Cruz-Agüero J. 2014. DNA sequence data analysis supports the taxonomic status of Eucinostomus dowii within the genus (Perciformes: Gerreidae). Journal of Ichthyology 54 (10): 872-881. DOI: $10.1134 / \mathrm{S} 0032945214100105$

Matthews W.J. 1998. Patterns in freshwater fish ecology. Chapman and Hall, Norwell, MA, USA.

Milano D., Cussac V.E., Macchi P.J., Ruzzante D.E., Alonso M.F., Vigliano P.H., Denegri M.A. 2002. Predator associated morphology in Galaxias platei in Patagonian lakes. Journal of Fish Biology 61 (1): 138-156. DOI: 10.1111/j.1095-8649.2002.tb01742.x

Milano D., Ruzzante D.E., Cussac V.E., Macchi P.J., Ferriz R.A., Barriga J.P., Aigo J.C., Lattuca M.E., Walde S.J. 2006. Latitudinal and ecological correlates of morphological variation in Galaxias platei (Pisces, 
Galaxiidae) in Patagonia. Biological Journal of the Linnaean Society 87 (1): 69-82.

DOI: $10.1111 /$ j.1095-8312.2006.00556.x

Palumbi S.R. 1996. [Chapter 7] Nucleic acids II: the polymerase chain reaction. Pp. 205-247. In: Millis D.M., Mortiz C., Mable B.K. (eds.) Molecular Systematics. 2nd edn. Sinauer Associates, Sunderland, MA, USA.

Saitou N., Nei M. 1987. The neighbor-joining method: A new method for reconstructing phylogenetic trees. Molecular Biology and Evolution 4 (4): 406-425.

Tamura K., Peterson D., Peterson N., Stecher G., Nei M., Kumar S. 2011. MEGA5: Molecular evolutionary genetics analysis using maximum likelihood, evolutionary distance, and maximum parsimony methods. Molecular Biology and Evolution 28 (10): 2731-2739.
DOI: $10.1093 / \mathrm{molbev} / \mathrm{msr} 121$

Vergara-Solana F.J., García-Rodriguez F.J., Tavera J.J., De Luna E., De La Cruz-Agüero J. 2014. Molecular and morphometric systematics of Diapterus (Perciformes, Gerreidae). Zoologica Scripta 43 (4): 338-350. DOI: $10.1111 /$ zsc. 12054

Ward R.D., Zemlak T.S., Innes B.H., Last P.R., Hebert P.D.N. 2005. DNA barcoding Australia's fish species. Philosophical Transactions of the Royal Society of London. Series B, Biological Sciences 360 (1492): 1847-1857.

DOI: $10.1098 /$ rstb.2005.1716

Zar J.H. 2010. Biostatistical Analysis. Prentice Hall/ Pearson, Upper Saddle River, NJ, USA.

Received: 26 October 2015

Accepted: 8 December 2015

Published electronically: 31 December 2015 